\title{
Maintenance of Russian as a heritage language in Germany: A longitudinal approach
}

\author{
Bernhard BREHMER \\ University of Konstanz \\ Konstanz, Germany
}

\begin{abstract}
The study discusses the perspectives of long-term maintenance of Russian as a heritage language in Germany. Based on data from a longitudinal study (2014-2018) we investigated changes in the sociolinguistic situation of 19 adolescent heritage speakers and in their proficiency in Russian. The aim was to investigate whether changes in the participants' sociolinguistic situation are reflected in their knowledge of Russian. Data on the sociolinguistic situation were collected via an extensive questionnaire that the participants had to fill out once a year. Language proficiency was measured by experimental tasks targeting different linguistic domains. For the current paper, we used data from the longitudinal measurement of lexical and grammatical proficiency. The results revealed that the participants' exposure to Russian input is decreasing in several domains over time, especially concerning media consumption and personal visits to the homeland. Russian is increasingly restricted to interactions with parents, and to educational settings (classes in Russian as a foreign or heritage language). Regarding language attitudes, our participants explicitly consider Russian important primarily for family interactions and cultural factors, but less with regard to career goals. Nevertheless, there was a positive trend in lexical and grammatical proficiency. We interpret these findings as a result of the prolonged exposure to heritage language instruction which leads to a stabilized proficiency in Russian. Given the institutional support and the size of the community, we hypothesize that the perspectives for long-term maintenance of Russian as a heritage language in Germany are better than for Russian heritage speaker communities in other countries.
\end{abstract}

Keywords: Russian, heritage language, sociolinguistic factors, language attitudes, language proficiency, Germany

For citation:

Brehmer, Bernhard. 2021. Maintenance of Russian as a heritage language in Germany: A longitudinal approach. Russian Journal of Linguistics 25 (4). 855-885. https://doi.org/10.22363/2687-0088-2021-25-4-855-885

Научная статья

\section{Сохранение «эритажного» русского языка в Германии: лонгитюдный подход}

\section{Бернхард БРЕМЕР}

Констанцский университет

Констанц, Германия

\section{Аннотация}

В статье рассматриваются перспективы длительного сохранения русского языка как эритажного (унаследованного) в Германии. При помощи лонгитюдного исследования (2014-2018 гг.) мы изучили изменения социолингвистической ситуации у 19 носителей русского эритажного языка 
в подростковом возрасте параллельно с изменениями в их владении русским языком. Целью исследования было выяснить, отражаются ли изменения социолингвистической ситуации участников на знании языка. Данные о социолингвистической ситуации были собраны с помощью подробной анкеты, которую участники заполняли раз в год. Уровень владения языком проверялся с помощью экспериментальных заданий в различных языковых областях. В настоящей работе мы использовали данные лонгитюдного анализа знаний в области лексики и грамматики. Результаты показали, что с течением времени у подростков количество контактов с русским языком в разных сферах его употребления снижается. Особенно это касается потребления СМИ и частоты личных визитов на родину родителей. Русский язык все больше ограничивается общением с родителями и образовательной средой (занятия русским языком как иностранным или унаследованным). Что касается отношения к языку, то подростки однозначно считают русский язык важным в первую очередь для семейного общения и сохранения культуры, но в меньшей степени для профессиональных целей. Тем не менее, наблюдалась положительная тенденция в лексическом и грамматическом владении языком. Мы интерпретируем эти результаты как итог длительного обучения унаследованному языку, что приводит к стабилизации уровня владения им. Учитывая институциональную поддержку и количество носителей русского языка, мы предполагаем, что перспективы длительного сохранения эритажного русского языка в Германии лучше, чем у русскоязычных сообществ в других странах.

Ключевые слова: русский язык, «эритажный» (унаследованный) язык, соииолингвистические факторы, отношения к языку, знание языка, Германия

\section{Для цитирования:}

Brehmer B. Maintenance of Russian as a heritage language in Germany: A longitudinal approach. Russian Journal of Linguistics. 2021. Vol. 25. № 4. P. 855-885. https://doi.org/10.22363/2687-0088-2021-25-4-855-885

\section{Introduction}

Since the dissolution of the Soviet Union Russian has become one of the most widely spoken allochthonous minority languages in Germany (cf., among many others, Besters-Dilger 2013, Brehmer 2007, Isurin \& Riehl 2017). Estimations of the number of Russian-speaking inhabitants in Germany vary from 2 to 6 million speakers, depending on the criteria applied to count speakers of Russian in Germany (e.g., place of birth, L1 speakers, heritage speakers, foreign language learners etc., see Lokshin 2020). According to official statistics, more than 3.5 million people who lived in Germany in 2017 either immigrated themselves from states of the former Soviet Union to Germany or had at least one parent who did so (Statistisches Bundesamt 2018: 130). Among them, 1.38 million people have their roots in the Russian Federal Republic (Statistisches Bundesamt 2018: 127). While we can safely assume that individuals who immigrated as adults from Russia and possibly also other member states of the former SU retain at least a basic knowledge of Russian, this cannot be presupposed for people who immigrated as small children or were even born in the new host country. Only 1.1 million people who came from the Russian Federal Republic to Germany migrated themselves. Consequently, more than 280.000 individuals were born in Germany to families, where at least one parent is an L1 speaker of Russian (Statistisches Bundesamt 2018: 130). It is this group of individuals that we will focus on in our contribution. As usual in 
linguistic research, we will use the label 'heritage speakers' to refer to this group: "A heritage speaker is an early bilingual who grew up hearing (and speaking) the heritage language (L1) (in our case: Russian, B.B.) and the majority language (L2) (in our case: German, B.B.) either simultaneously or sequentially in early childhood (...), but for whom L2 became the primary language at some point during childhood (at, around, or after the onset of schooling). As a result of language shift, by early adulthood a heritage speaker can be strongly dominant in the majority language, while the heritage language will now be the weaker language" (Benmamoun et al. 2013: 133). Given the fact that the peak of immigration from countries of the former Soviet Union to Germany was in the early 1990s, the offspring of the first generation of Russian-speaking immigrants are currently building their own families which inevitably involves the decision whether to transmit their heritage language Russian to the following (= third) generation or not.

For this reason, our contribution focuses on the perspectives of long-term maintenance of Russian as a heritage language in Germany. Due to the significant number of speakers of Russian in Germany, there has been a constantly growing body of research on (heritage) Russian in Germany. The sociolinguistic studies among them tackle the question of the general vitality of Russian as a minority language in Germany (cf. Achterberg 2005), but also issues related to language use and attitudes in families (Anstatt 2013, 2017, Levkovych 2012, Ries 2013) or identity matters (e.g. Dietz \& Roll 2017, Isurin 2011, Meng \& Protassova 2003, 2009, 2013, Schnar 2010, Ždanova 2004, 2008a, 2008b). Most of the (socio)linguistic studies on Russian in Germany share one feature: they rely on data drawn from cross-sectional designs only. In case that developmental tendencies are addressed in the papers, the respective observations are based on a comparison of different age groups of Russian heritage speakers (apparent time approach, cf., e.g., Böhmer 2015 or Brehmer \& Usanova 2017) or on a comparison of first- and secondgeneration immigrants from the former Soviet Union (cf., e.g., Brehmer \& Mehlhorn 2015, Brehmer \& Kurbangulova 2017 or Warditz 2019). 'True' longitudinal designs which focus on the linguistic trajectories of individuals or the development of sociolinguistic factors over the life-span of Russian-German bilinguals are clearly the exception. In this respect, the data discussed in studies by Meng and Protassova (cf., e.g., Meng 2001 and Meng \& Protassova 2017) are almost the only source of information on long-term bilingual development of speakers of Russian in Germany. They followed several families of Russian Germans (Russian: русские немиы, German: Spätaussiedler 'repatriates'), i.e. ethnic Germans who repatriated to Germany from the former Soviet Union in the early 1990s, in a systematic participant observation from the time of their arrival in Germany over a time span of more than 20 years. Although the authors established some common trends in the development of sociolinguistic factors as well as their impact on the proficiency in both languages (cf. Meng \& Protassova 2017), the studies lack a systematic and quantifiable analysis of the interplay between the selfreports and the linguistic data throughout the observed time span. 
To address this research gap, we conducted a longitudinal analysis of a sample of adolescent Russian heritage speakers where we focused both on the development of sociolinguistic factors which shape the process of language maintenance and/or language loss, and the linguistic development of their heritage language Russian. Section 2 provides a brief summary of previous research on sociolinguistic factors which impact on language maintenance in heritage speakers of Russian. In Section 3 we introduce the research questions of the current study, followed by the introduction of our study design and the participants in Section 4. Section 5 presents the results regarding the development of some selected sociolinguistic factors and aspects of the participants' proficiency in heritage Russian over the investigated time span. Section 6 discusses the results and the interrelation between the sociolinguistic and linguistic developmental trends in our sample of speakers. The paper ends with some general conclusions and an outlook on some open questions that we could not address in our paper.

\section{Sociolinguistic factors shaping language maintenance in Russian heritage speakers}

Due to the fact that populations of Russian heritage speakers can be found in many countries all over the world, there have been quite a lot of attempts to identify (socio)linguistic factors which influence the maintenance and transmission of Russian to the following generation(s) (cf., among others, Armon-Lotem et al. 2011, Gagarina \& Klassert 2018, Eriksson 2015, Karpava et al. 2018, Otwinowska et al. 2021, Rodina et al. 2020, Zemskaja 2001). Building on general models of assessing language vitality in immigrant settings (Lo Bianco 2008, Lo Bianco \& Peyton 2013), Laleko (2013) mentions three groups of factors which prove to be the most influential parameters of language maintenance and shift in the Russianspeaking community in the U.S.:

\subsection{Sources of capacity development in Russian heritage language acquisition}

Capacity refers to "the level of knowledge that heritage speakers of Russian have in the heritage language and the factors that create conditions for development of such capacity" (Laleko 2013: 89). These factors include possibilities to receive formal instruction in the heritage language, e.g. by attending community schools or other extra-curricular educational settings which target heritage language learners. The extent to which such community schools or other opportunities for receiving heritage language instruction are available depends on the countries of residence: while the situation in the U.S. seems to be characterized by a lack of community schools for heritage learners of Russian (Kagan 2005: 213f., cited in Laleko 2013), Russian-speaking parents in Germany can get major support in their efforts to transmit Russian to their children from various institutions. These include public schools which offer classes of Russian as a foreign or heritage language, Saturday/Sunday (community) schools as well as cultural, church or private institutions which organize language courses but also different leisure activities 
where children can get acquainted with various aspects of Russian culture ${ }^{1}$. However, the availability of such offers varies regionally due to the federal educational system in Germany. Especially in rural areas access to external support in heritage language transmission is often limited. Furthermore, even when such support is established locally, the use of these opportunities is always linked to additional efforts (regarding time and perhaps also money) for the families. It also requires a high level of motivation from the children's side. Thus, it is "not uncommon for parents to serve as the primary (and often only) source of linguistic input for children in immigrant families. For Russian, language exposure at home emerges as the most significant factor in heritage language maintenance and transmission" (Laleko 2013: 93f.). The success of intergenerational transmission of Russian crucially depends on the patterns of daily language use at home, i.e., the amount of input the children receive in their heritage language from other family members. Studies on family language policies in Russian heritage communities revealed a direct correlation of successful transmission of the heritage language Russian with parental language preferences, repertoires and active use of Russian in the families (see, among many others, Eriksson 2015, Karpava et al. 2018, Kopeliovich 2010, Otwinowska et al. 2021). Again, the circumstances for Russian heritage speakers to receive sufficient encouragement from their parents to actively use Russian on a daily basis seem to be more favorable in the European context when compared to the U.S. ${ }^{2}$ The parents' decision regarding the amount and consistency of the use of the heritage language in family interactions reflects such considerations like the need for communication with the extended family in their countries of origin, the frequency of contact with other bilingual families in the host country, the social and educational environment (SES, level of education and/or employment status of parents etc.) or psychological factors (e.g. degree of integration in the host society, attitudes towards majority and heritage language and culture etc.) (see Karpava et al. 2018 for an overview of relevant research on these factors).

\subsection{Opportunities for the use of Russian in different domains}

Besides the amount of passive exposure to the heritage language, the possibility to actively use Russian in a wide range of contexts is another crucial factor for language maintenance by heritage speakers of Russian. Given the large size of the Russian-speaking community in Germany (cf. Section 1) and the rather small size of the host country (compared, e.g., to the U.S.) as well as the still

\footnotetext{
${ }^{1}$ See, e.g., Brehmer \& Mehlhorn (2018) for an illustration of the range of possibilities to receive Russian heritage language instruction in Germany. Kreß (2014) offers insights into the structure, topics and organization of Russian heritage language instruction in one community school in Lower Saxony.

${ }^{2}$ See Laleko (2013) and the studies cited therein for the American context vs. the above mentioned studies on family language policies in Russian-speaking families in several European countries like Sweden, Ireland, Estonia or Cyprus.
} 
ongoing immigration from Russian-speaking countries to Germany (although on a much lower level compared to the 1990s), the general prospects for Russian language maintenance are quite favorable. Although the majority of Russian speakers does not live in clearly defined ethnic or linguistic neighborhoods in Germany (with some local exceptions, see Dück 2020: 304), which might also be a consequence of the Russian-speaking population's heterogeneity in Germany ${ }^{3}$, there are quite numerous opportunities to use Russian outside the home. Especially in major cities and large metropolitan areas the Russian-speaking diaspora in Germany has established close social, cultural and educational networks and an infrastructure supporting the use of Russian in different domains outside the family circle: clubs, cultural associations, religious organizations, Saturday/Sunday schools, cafes and restaurants, ethnic shops and grocery stores which offer Russianlanguage press, films, books or foodstuffs, but also their 'own' travel and insurance agencies, medical offices, lawyers, discotheques or nursery schools (Besters-Dilger 2013: 189). The availability of public services and business in Russian also provides employment opportunities where knowledge of Russian is required ${ }^{4}$. Furthermore, with the advance of the Internet and subsequent developments towards global interconnectedness (including e-mails, social networks, Skype, satellite radio and television) both access to Russian-language media (from the homeland and from Germany-based providers) and possibilities to maintain links with people, culture and life in the countries of origin are nowadays virtually unlimited. However, despite these most favorable sociolinguistic conditions for language maintenance, the question arises to what extend the individuals make use of these facilities. Laleko (2013: 95f.) reports results from studies on media use among second-generation Russian Americans which reveal that "these growing

${ }^{3}$ The Russian-speaking population in Germany is split into three distinct groups that are distinguished not only by their histories and motivations to come to Germany: (i) Russian Germans, i.e., ethnic German repatriates from the former Soviet Union who were immediately eligible for German citizenship after their arrival; (ii) Jews from the former Soviet Union who were allowed to enter Germany in the 1990s in order to strengthen the Jewish communities in Germany; (iii) ethnic Russians who immigrated to Germany due to various motivations and under different legal circumstances (students, au pairs, scientists, spouses etc.) (cf. Besters-Dilger 2013, Brehmer 2007 or Isurin \& Riehl 2017). Despite their common linguistic background with Russian as their L1, they differ with respect to ethnicity, geographic, economic and educational backgrounds, their legal and socio-political status in Germany, but even more so regarding their language attitudes and affiliation to the Russian culture. As a consequence, the single groups often show a high degree of internal coherence (including a preference for in-group marriages and friendships, see Meng \& Protassova 2017: 189), and often avoid close contact with members of the other groups (cf. Behrend 2014 or Isurin \& Riehl 2017). While differences in identity building and language attitudes have been already addressed in research (cf., e.g., Irwin 2017), there is still no study that systematically investigates possible differences between these groups concerning actual L1 maintenance.

${ }^{4} \mathrm{We}$ know from studies on L1 attrition that the use of the home language in professional contexts (i.e. as a translator, teacher etc.) is a very strong predictor for language maintenance (cf. Schmid \& Dusseldorp 2010). Zemskaja (2001) also stresses the importance of the use of Russian in professional settings (“русский язык - кормилец”) as a main motivation to preserve the heritage language. 
opportunities do not seem to change the established patterns of preference for English-language media", so that the heritage speakers "listen predominantly to American music, watch American movies, and spend time on the Internet visiting English language websites". The latter tendency cannot be accounted for by the lack of literacy skills in Russian, because even the majority of those heritage speakers who acquired basic literacy skills do not to access Russian internet resources or read in Russian outside of school (Carreira \& Kagan 2011, cited in Laleko 2013: 96).

\subsection{Heritage learner motivations and desire for continued use of Russian}

The last group of factors concerns mostly the attitudes of heritage speakers and their parents towards maintenance of Russian and its transmission to the next generations. Positive attitudes towards Russian are also a prerequisite for capacity building and making an effort for creating opportunities for language use within and outside the family circle. Consequently, "linguistic attitudes may directly influence the choice of language in certain situations" and have "an indirect effect on the acquisition and attrition of linguistic structures themselves" (Anstatt 2017: 204). In her empirical study on language attitudes among second-generation speakers of Russian in Germany, Anstatt (2017) - following a model proposed by Garrett (2010) - distinguishes between three different components of individual dispositions towards languages which strongly interact and overlap to a certain extent:

(i) Affective language attitudes relate to "feelings like pride or comfort using the language, to aesthetic judgments and to loyalty towards the language" (Anstatt 2017: 205). These feelings are often connected with a general desire to maintain autonomy and distinctiveness from the host culture or with a desire for identification with the majority group.

(ii) Cognitive components of language attitudes are of a more objective nature and pertain to "judgments about the perceived benefit from the language", i.e. the belief that the language can be useful in certain situations (Anstatt 2017: 208).

(iii) Behavioral attitudes include aspects of the predisposition to use a language in a given situation and therefore overlap with factors that were discussed in Section 2.2. Thus, Anstatt treats answers to questions concerning the frequency of use of Russian in different situations that allow for a relatively free language choice as indicative of language preferences and, therefore, as reflecting behavioral attitudes towards the heritage language (Anstatt 2017: 209).

All three components are inevitably influenced by the real and/or perceived prestige of the heritage language in the host community ${ }^{5}$.

${ }^{5}$ In an interesting study on Russian in Israel, Remennick (2003) could show how the increasing ethnic power of Russian speakers during the 1990s and the ensuing higher status of Russian as the most important immigrant language in Israel motivated members of earlier waves of immigration from the Soviet Union to Israel to return to Russian as a means of everyday communication after many years of oblivion. 


\subsection{Vitality of heritage Russian in Germany: Observations from previous studies}

For the American context, Laleko (2013: 98) states that the main motivation of heritage speakers to maintain Russian "is fueled to a large extent by affective, rather than purely practical, factors and aims first and foremost at preserving familial continuity and strengthening emotional ties to the cultural heritage". Thus, it is considered predominantly as a "bridge to the past". Professional goals are hardly mentioned as the driving force for (re-)learning the heritage language which according to Laleko points to the rather few opportunities that knowledge of Russian provides in the American job market. It is for these reasons that Laleko provides a rather pessimistic view on the future of Russian as a heritage language in the U.S. She considers it to be an endangered language which does not survive beyond the second generation (cf. Laleko 2013: 89). Previous research on linguistic vitality of Russian as a heritage language in Germany reveals some striking parallels to these observations, but differs with regard to predictions regarding its future. Thus, Russian is the language that yields the highest scores on the vitality index proposed for Slavic immigrant languages in Germany in the comparative study of Achterberg (2005). However, this prominent position is mostly due to the size of the community as well as its role as the dominant and most frequently used language for everyday communication within and partly also outside the family (Achterberg 2005: 252). Two caveats have to be mentioned when interpreting these results: First, data collection for Achterberg's study took place in the early 2000s, so 20 years have passed since then which might lead to divergent results when the current situation is under focus. Second, Achterberg did not distinguish between first- and second-generation immigrants which does not allow to draw more finegrained conclusions with regard to the vitality of Russian as a heritage language for people who were already born in the host country. An additional hint that the situation for heritage Russian in Germany might not be so different from the American context comes from the results of Anstatt's study on language attitudes of second-generation speakers of Russian in Germany (Anstatt 2017): Based on data from questionnaires and interviews with adolescent heritage speakers, she found that "Russian (...) is a language with a high affective value and enjoys a very high loyalty. It is closely linked to home and parents, and, somewhat less, to the maintenance of Russian culture" (Anstatt 2017: 210). German, on the other hand, is seen as less emotionally charged, but as a prerequisite for educational and professional success, and also as the language for communicating with peers, even with those who come from Russian-speaking families (Anstatt 2017: 210). This resembles very closely the "division of labor" between heritage and majority language which Laleko found for American Russian.

\section{Aims of the present study}

The current study specifically addresses the development over time of these three groups of sociolinguistic factors that shape Russian language maintenance in 
a sample of adolescent heritage speakers. In contrast to previous studies, our data rely on a longitudinal design where we focused on the situation of secondgeneration speakers of Russian. We believe that it is this group of adolescent speakers who function as important decision-makers in questions of long-term maintenance of Russian in Germany. They play an important role in passing down a certain attachment to the Russian language and culture which will be decisive for the future of Russian in Germany (Eriksson 2015, Anstatt 2017). As Isurin and Riehl (2017: 5) state: "By looking at the second or 1.5 generation (...) of Russian migrants/repatriates we can project how integration, language acquisition, and attitudes toward language and culture maintenance shape those young people who might claim Germany as their home". The specific situation of the second generation is very often stressed in heritage language research: On the one hand, there is the heritage language as the language of their families and the necessary link to maintain relationships with relatives and acquaintances in the countries of origin. On the other, there is the majority language as the language of education, employment and main means of communication with the environment (including peers). There seems to be a general agreement in heritage language research that the majority language almost inevitably develops into the primary language, whereas the heritage language turns into a secondary language which might be associated with some emotional value, but serves rather restricted functions in everyday life. Thus, it is predicted that the situation of the second generation is characterized by a steady decline of the use of the heritage language throughout the life-span and a rapid adoption of the majority language which gradually replaces the heritage language (see the definition for 'heritage speaker' cited in Section 1). It remains to be seen whether this characterization also fits the situation of Russian as a heritage language in Germany. The research questions that we want to address here include the following:

RQ1: Do the sociolinguistic factors that have been identified as shaping the probability of heritage language maintenance (cf. Section 2) change over time in the examined sample of adolescent Russian heritage speakers in Germany?

RQ 2: Is the development of these factors accompanied by observable trends in the development of linguistic proficiency in the heritage language?

RQ3: Can the results obtained from RQ1 and RQ2 serve as predictors regarding long-term preservation of Russian as a heritage language in Germany?

\section{Material and method}

\subsection{Participants}

The data were gathered in a longitudinal project on Russian as a heritage language in Germany. Data collection started in summer 2014 and ended in 2018, with every participant being tested once a year (apart from 2016). When data collection started in 2014, we had 28 participants from Russian-speaking families who lived in two German metropolitan areas: Hamburg $(n=16)$ and Leipzig $(n=12)$. Four years later 19 participants took part in the last wave of data collection 
(ten from Hamburg and nine from Leipzig). As our study addresses the longitudinal development, only those participants were included in the sample who took part in all four points of data collection $(2014,2015,2017,2018)$. Table 1 offers an overview of these 19 participants' basic demographic characteristics.

Table 1

Participants' demographic characteristics

\begin{tabular}{ll}
\hline \multicolumn{1}{c}{ Variable } & \multicolumn{1}{c}{ Participants } \\
\hline Sex & 9 males; 10 females \\
Age at first testing (mean (SD)) & $12.3(0.82)$ \\
Place of birth & Germany $(n=12)$ \\
& Russian Federation $(n=4)$ \\
& Ukraine, Kazakhstan, Uzbekistan (per each $n=1)$ \\
Age at immigration [foreign borns] (mean (SD)) & 10.1 months $(5.2)$ \\
Group affiliation & Russian Germans $(n=8)$ \\
& Jewish $(n=6)$ \\
Educational background & Mixed families $(n=4)^{6}$, Others $(n=1)$ \\
& Higher secondary school $(n=16)$ \\
Access to (any kind of) Russian language & Middle secondary school $(n=3)$ \\
instruction & yes $(n=14)$, no $(n=5)$ \\
\hline
\end{tabular}

For our study, we specifically focused on teenage heritage speakers who had rather recently started to attend secondary school (grades 6 and 7). According to the literature (see Section 1), this is the time where a shift to the majority language as the dominant language is expected. On the other hand, at least some of our informants had the possibility to select their heritage language Russian as a regular school subject. Two participants took advantage of this and attended lessons in Russian as a second foreign language starting from grade 6. Our sample is certainly not representative of all adolescents who grow up in Russian-speaking families in Germany, which limits the possibility to generalize the findings. First, $74 \%$ of our participants had at least some exposure to heritage language instruction (see Section 5.1. for more details). Second, their educational background is rather strong: $84 \%$ attend a higher secondary school, which is above average for children with a migration background in Germany. Third, as we recruited our sample in two German major cities (Hamburg, Leipzig), our findings reflect the situation in urban contexts rather than in rural areas, where the possibilities for gaining external support for heritage language development are more limited. Furthermore, the

\footnotetext{
${ }^{6}$ In all mixed families except one Russian functions or functioned (in case the parents are now divorced) as the main means of communication: In two families the fathers are from Afghanistan, but lived in Russia or Ukraine for a longer period, where they met their partners (one mother is Russian, the other is Ukrainian). In another family the mother is German, but studied and worked in Russia for many years. Then, there is one family in our sample where the father is German and does not speak Russian, but the mother is an ethnic Russian and speaks her mother tongue to her children. And finally, in one family both parents were born in the Russian Federation, but did not disclose their affiliation to one of the above mentioned groups ('Others').
} 
sample is biased since participation in the study was on a voluntary basis. Consequently, our study attracted mostly families with a high interest (and presumably also confidence) in taking measures to secure Russian language maintenance by their children. If, however, we will find a decline in Russian language use or a declining status of Russian over the examined time span even in these adolescents, the perspectives for heritage language maintenance of Russian in Germany in general do not look very promising.

\subsection{Data collection}

Our data collection proceeded in several steps: We gathered data for the sociolinguistic part of our study via an extensive written questionnaire that contained 34 mostly closed questions regarding (i) biographic information; (ii) the participants' language biography and acquisition; (iii) their attitudes towards the heritage and majority language; (iv) their language use and preferences in different communicative situations inside and outside of the family; (v) factors that might influence their language choice and the likelihood of code-switching when communicating with other people from the same linguistic background; (vi) the intensity of contact with people residing in the countries of origin. The questionnaires were delivered during all phases of data collection (i.e. once a year), which leads to a total of four completed questionnaires per participant. Questionnaires were not only distributed to the adolescents, but also separately to their mothers in order to cross-check the answers given by our adolescent participants with the answers delivered by their parents (e.g. regarding language use in the families). As an additional step, we conducted semi-structured in-depth oral interviews on the linguistic situation in the family and language attitudes with both adolescents and their parents to enrich and validate the data that were collected through the questionnaires. The interviews were transcribed, relevant topics were coded and analyzed against the data that were gathered in the questionnaires. For both questionnaire and interview, the participants could choose the language they felt most comfortable in (German or Russian). For the present investigation, however, we will focus on the quantitative data obtained from the questionnaires.

As we did not want to solely rely on the self-assessments of the proficiency in the heritage language, our informants were exposed to a large test battery. The tests mostly aimed at eliciting experimental, but also semi-spontaneous production data that targeted different domains (lexicon, grammar, phonetics). Furthermore, we used tests that provided data on different modalities of skills (oral comprehension, reading comprehension, reading aloud, writing, mediation) in the heritage and partly also the majority language (for a comprehensive overview on the applied test battery see Brehmer \& Mehlhorn 2015). For the purpose of the current study, we will restrict ourselves to longitudinal data that targeted vocabulary knowledge and grammatical proficiency in Russian. For assessing lexical skills, we used a wordlist/vocabulary task where the informants had to translate a list of 100 words from 
German to the heritage language Russian $(n=50)$ and vice versa $(n=50)$. The test items were selected to include all parts of speech, different semantic domains and also different degrees of frequency. For each correctly translated item the participants scored one point, leading to a maximum score of 100 (see Brehmer et al. 2017 for more details on the vocabulary task). The participants had to take the same test with the same items at each wave of data collection. The same applies to the test on grammatical proficiency, where we used a Cloze test which targeted knowledge of nominal and verbal morphology in Russian. The test consisted of a coherent text in Russian that depicted a retelling of an episode taken from the famous Maša i Medved' cartoon movie. The text contained 74 gaps overall that had to be filled by the participants who had to use the correct grammatical form of the respective word that was given in the base form (nominative singular for nouns, pronouns and adjectives; infinitive for verbs) in brackets following the gaps. The test items focused mainly on nominal case inflection $(\mathrm{n}=30)$ and verb inflection $(\mathrm{n}=32)$. The test was delivered as a paper-and-pencil task for participants who could read and write in Russian. Orthographic errors were neglected when scoring the results for each participant. For illiterate participants each sentence of the text was read out orally by the test instructor and the participants had to give the correct grammatical form for each test item. In order to avoid learning effects the text was rewritten for data collection waves three and four, but the test items and target forms stayed the same. Test administrators were all L1 speakers of Russian. Interviews/questionnaires and language tests were conducted on different days.

\section{Results}

\subsection{Sources of exposure to Russian}

Following the three groups of parameters that were distinguished by Laleko (2013) for assessing heritage Russian vitality in the U.S., we first present the results of our analysis regarding the answers to questions which targeted the conditions for developing proficiency in the heritage language. This includes the possibility to receive formal instruction in the heritage language. One characteristic feature of the participants in our sample is that almost all of them attended schools or private organizations that offered Russian language courses. Only five participants (26\%) were never exposed to formal teaching in Russian. The extent to which the other participants attended heritage language instruction, however, differs. As stated earlier, two participants selected their heritage language Russian as a regular school subject starting from grade 6 with an average amount of 4 lessons per week. Both of them had had already earlier exposure to teaching of Russian, because they attended Russian language courses which were offered by different state or private institutions while they went to kindergarten and/or elementary school. The same applies to the other participants in our sample who took Russian language classes at community schools or other extra-curricular educational settings, including private initiatives like organizing home classes (see Brehmer \& Mehlhorn 2018 for 
details). Three participants (16\%) had already stopped attending Russian language classes before we started collecting our data in 2014, another three participants quit these extra-curricular activities during the longitudinal study. The duration of attendance of these additional courses exceeds five years and more for most of our participants; only three participants received instruction in the heritage language between two and four years. The amount of lessons per week also varies between 1.5 and 3 hours. Thus, the ratio of participants who have been exposed to formal instruction in their heritage language over a longer period is very high in our sample and stands in stark contrast to the situation in the U.S., where "[a]ccording to the most recent data, in a sample of 254 heritage learners of Russian, $84.3 \%$ have never studied Russian at a community or church school, and only $14.7 \%$ reported having attended a community or church event in their heritage language within the last six months" (Laleko 2013: 92).

As a next step, we analyzed language preferences for everyday communication within the family as a proxy for the amount of input that the adolescents receive in their heritage language at home. Figure 1 depicts the total number of participants who stated that they use only or predominantly Russian when addressing members of their core family (mother, father ${ }^{7}$, siblings) or that they are addressed only or predominantly in Russian by the respective family members. The picture evolving from the answers reveals a quite typical pattern for heritage language settings: The heritage language does not play a significant role in communicating with siblings, and this does not change throughout the examined period. It is mostly mothers (13-15 out of a total of 19) who address their adolescent children only or predominantly in Russian, while the number of fathers that use at least predominantly the heritage language when addressing their children is lower (8-9 out of 16). This might be related to the fact that in our sample mixed marriages consist of mothers with L1 Russian and fathers with other languages than Russian as L1, but even in most of these families Russian could have functioned as the language of intrafamily communication (see footnote 6). Thus, the rather low amount of adolescents (8-10) who perceived parent-parent communication to be predominantly or exclusively in Russian is striking.

Overall, the distribution of language preferences within the families stays rather stable over the examined period, with Russian playing a slightly less important role only during the second wave of data collection in 2015. A clearly positive trend can be established for Russian as the preferred language of the adolescents when they address their mothers: While in 2014 only ten informants declared that they use only or predominantly Russian when addressing their mothers, the number increased to 13 in 2018. Still, this does not eliminate the

\footnotetext{
${ }^{7}$ The number of answers regarding language practices of fathers and mothers varies due to the fact that three participants lived in single-mother households, because the parents were divorced and/or lived separately during the data collection procedure.
} 
asymmetry regarding the role of Russian as a preferred means of intrafamily communication between mothers and their children.

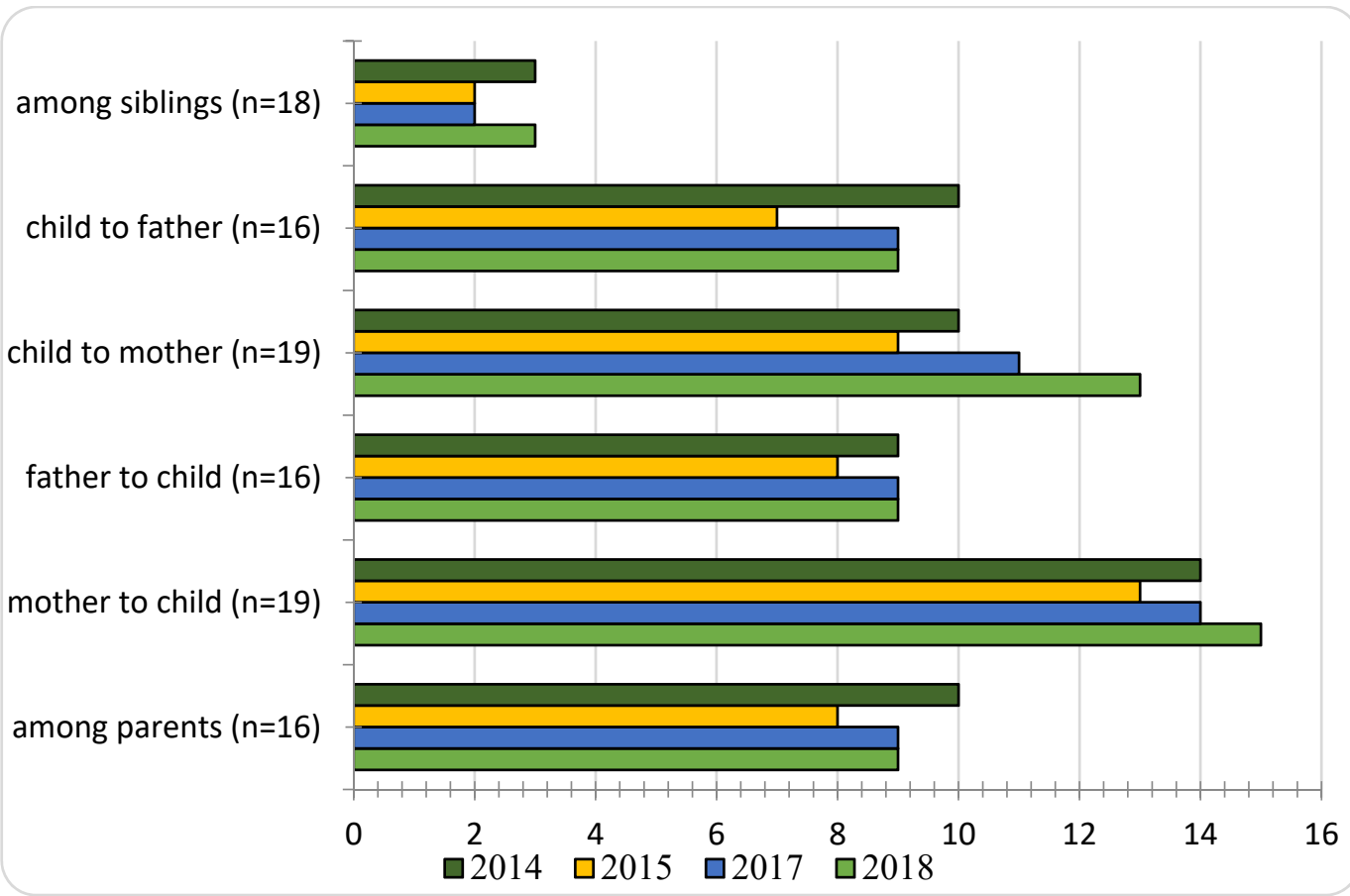

Figure 1. Exclusive or predominant use of Russian in interactions between family members

In order to gain insight into the consistency of language use in intrafamily communication, we asked our participants to reflect on their code-switching between Russian and German in interactions with different members of the core family. Figure 2 depicts the number of participants who stated that they regularly code-switch when communicating with the respective addressees. Again, the participants observed that they most often resort to code-switching when talking to their mothers which obviously mirrors the fact that mothers are most frequently addressed in Russian (see Figure 1). However, there seems to be a decrease in the amount of code-switching with parents over time. This clearly contrasts with codeswitching when talking to siblings where more participants reported on instances of code-switching in the later waves of data collection compared to 2014 (increase from six participants in 2014 to eight participants in 2018). Still, the ratio of use of Russian when communicating with siblings is obviously quite low in the investigated sample. 


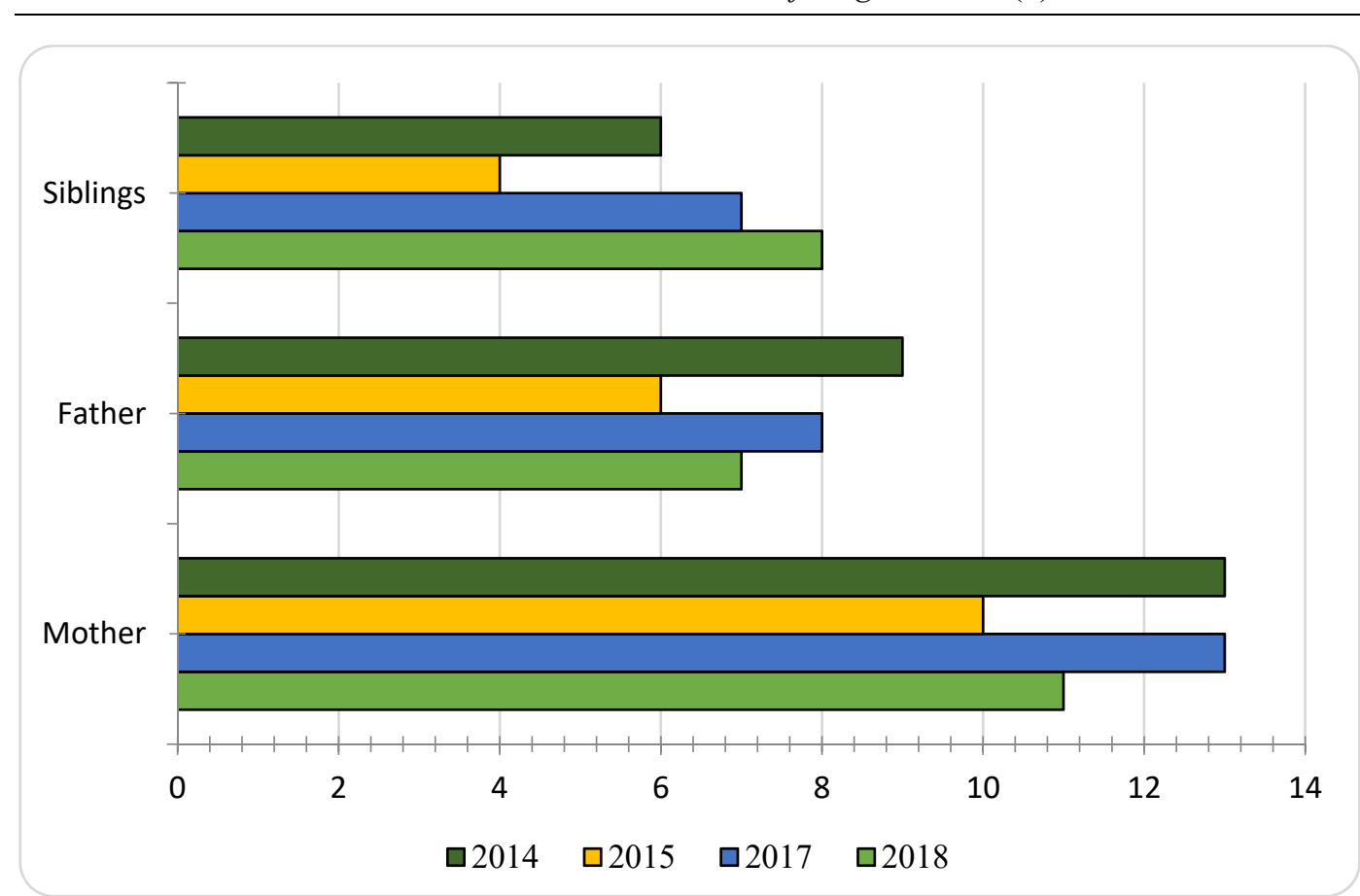

Figure 2. Regular code-switching when communicating with family members $(n=19)$

\subsection{Use of Russian in different domains}

Despite the highly developed Russian-speaking infrastructure in Germany mentioned in Section 2.2., the German host community clearly dominates the participants' social networks in our study, which limits the exposure to the heritage language Russian outside the family. ${ }^{8}$ Only one participant claimed to have a fellow student in school, with whom she engages in casual conversations in Russian. Three participants have Russian-speaking friends, which is why Russian is "sometimes" used for in-group communication. Regarding the immediate neighborhood, only two participants stated in 2014 that they sometimes use Russian when talking to neighbors or other adolescents living in the same district. During the later waves of data collection only one participant in 2018 reported on the same experience. Overall, there is neither an increase nor decrease in the low numbers of interlocutors outside the family with whom our participants can use Russian as a means of communication on a regular basis.

When asked about the efforts that are made to stay in touch with relatives and friends in the home countries of their parents, almost all participants (18 in 2014, 19 in 2015) claimed that they keep in touch with the countries of origin. These numbers drop, however, towards the end of our longitudinal studies: in 2017, only

${ }^{8}$ These observations contrast with findings from other studies. Meng \& Protassova (2017: 189) report that in their sample of Russian German young adults there is a clear tendency for in-group marriage and close relationships with other members of the same community. However, they also confirm that the preferred or only language of the informants among themselves is German, while Russian is only used occasionally. 
17 participants reported on such contacts, in 2018, 16 participants continued their communication with family members and acquaintances in Russian-speaking countries. Figure 3 shows the ways in which these personal contacts are maintained.

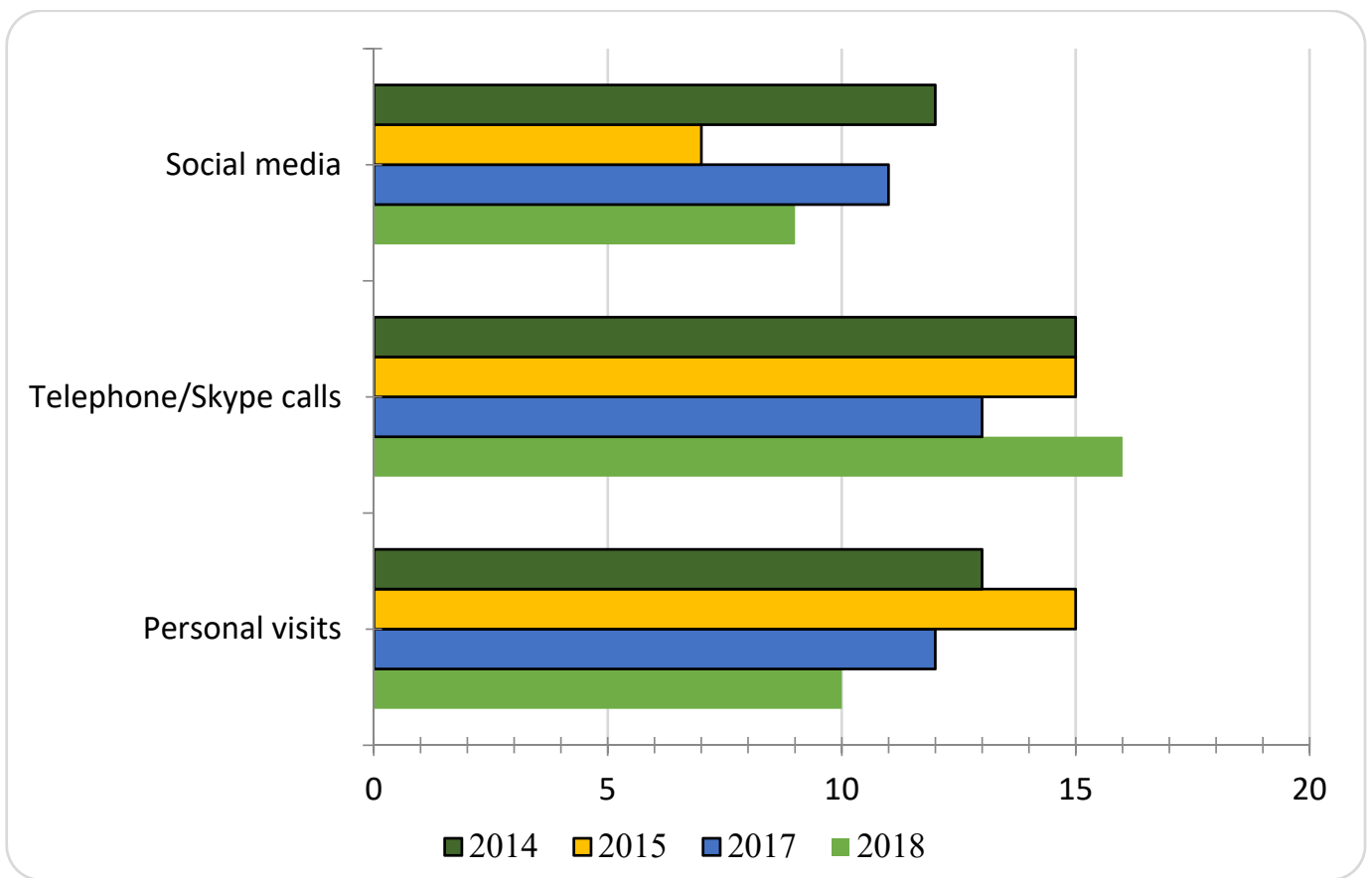

Figure 3. Ways of keeping in touch with relatives and acquaintances in the home countries

'Classical' telephone or skype calls are the preferred means for communicating with residents in the home countries, while the number of participants who pay regular personal visits drops from a maximum of 15 in 2015 to only ten in 2018 at the end of data collection. As the teenagers grow older, regular visits to the countries of origin obviously lose their attractiveness, which may be due to a preference for other holiday destinations or financial and administrative constraints (the need to apply for a visa). Communicating via social media plays a surprisingly marginal role, but this might be due to the fact that in most cases it is the grandparents or other elder relatives who still reside in the countries of origin, which does not make use of technically advanced media always feasible.

Media are another domain where the heritage language can be employed, e.g., for reading Russian websites or print media, watching Russian TV and films (via satellite or on the Internet) or listening to Russian music. With the advance of the digital age, heritage speakers nowadays have gained almost unlimited access to media in the heritage language, either produced in the countries of origin or by the local communities themselves, which are distributed on the Internet. Technical advance, thus, allows to counteract the geographical distance and "to participate, almost seamlessly and in real time, in the mainstream of Slavonic-language life of their homelands" (Kamusella 2013: 219). For Russian heritage speakers in the U.S., 
however, it was established that these media are used mostly by the elderly or middle-aged generation, while the younger generation clearly prefers Englishlanguage media (Dubinina \& Polinsky 2013: 163, Laleko 2013: 95f.). Figure 4 depicts the regular use of Russian-language media by our participants over the examined time span.

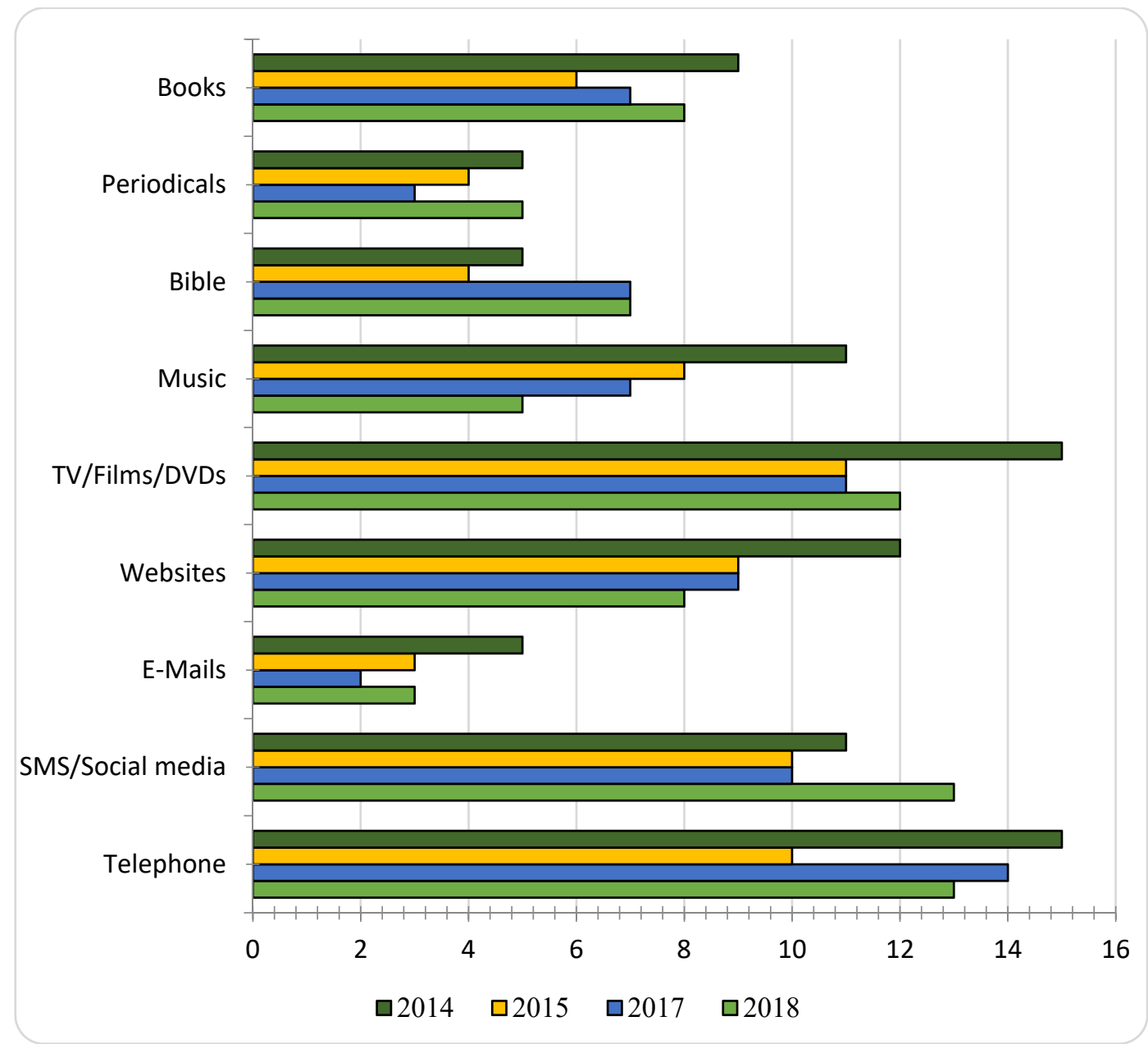

Figure 4. Regular use of Russian language by type of media

Our participants use their heritage language predominantly for media that enables them to stay in touch with friends and relatives (telephone, SMS, WhatsApp, social media like Facebook), with social media and short messenger services becoming a more important means over the examined period (13 out of 19 participants use Russian both for telephone calls and social media in 2018). Among the media that primarily serve entertaining functions our participants mostly resort to Russian-language TV programs and films, although the number of participants who regularly watch Russian films and TV programs is decreasing over time (15 in 2014, 12 in 2018). The same applies for visiting websites in Russian. 
An even more rapid decrease can be observed in the domain of listening to Russian music (11 participants in 2014, just five in 2018). ${ }^{9}$ Classical print media such as books or periodicals are regularly consumed in Russian only by a minority of participants in our sample, with Russian books being far more popular than periodicals. This might be related to the fact that there is a high share of participants who still attend heritage language classes or classes in Russian as a foreign language, where reading (excerpts of) texts in Russian comprises an integral part of the teaching program. Media that require the active composition of longer texts in Russian (E-Mails) are the least popular in our sample. Generally speaking, there is an average decline in the regular use of Russian in almost all types of media, but still the number of participants who use or consume media in Russian is comparatively high when compared, e.g., to heritage speakers of Russian in the U.S. (cf. Carreira \& Kagan 2011).

\subsection{Attitudes towards Russian}

The desire for maintaining the heritage language is crucially shaped by the degree of identification with the heritage language, the personal connection to it as well as the ethnic, linguistic and cultural identities of the heritage speakers (Laleko 2013: 97). In order to assess these factors in our sample, we focused on the affective components of attitudes towards the heritage and the majority language. Following a proposal by Anstatt (2017: 205), we analyzed answers to questions which "relate to feelings like pride or comfort using the language, to aesthetic judgments and to loyalty towards the language" as indicative of the degree of emotional identification with Russian and German. In a series of closed questions in the questionnaire our participants were asked to rate their assessment of several statements by using a five-point Likert scale (ranging from point $1=$ "I thoroughly disagree with this statement" to point $5=$ "I thoroughly agree with this statement"). Figure 5 depicts the scores for a couple of questions targeting the feeling of comfort our participants experience when they speak, hear, read and write Russian.

The participants feel on average very comfortable both when they hear and speak the heritage language and this does not change throughout the examined time span. When it comes to modalities of language use that require literacy skills (reading, writing), however, they clearly feel more uncomfortable and the degree of variation within the group increases considerably. This reflects more varied proficiencies in the realm of reading and writing among the participants which is a typical feature of heritage speakers (see Böhmer 2015 for heritage Russian in Germany). There is no clear developmental trend over time in either direction. Due to lack of space, we cannot go into detail regarding the corresponding values for the majority language German. Generally speaking, the participants show an equally,

\footnotetext{
${ }^{9}$ Here again, our sample seems to differ from other studies on Russian heritage speakers in Germany: Anstatt (2017) and Meng \& Protassova (2017) find for their informants that they consider it more customary to listen to Russian music than to watch Russian TV programs or films, as the high speech rate in Russian films makes it hard for them to follow.
} 
although on average slightly lower positive attitude towards speaking and hearing German when compared with Russian. However, the values for reading and writing reveal a higher degree of comfort when this is done in German compared to Russian. ${ }^{10}$

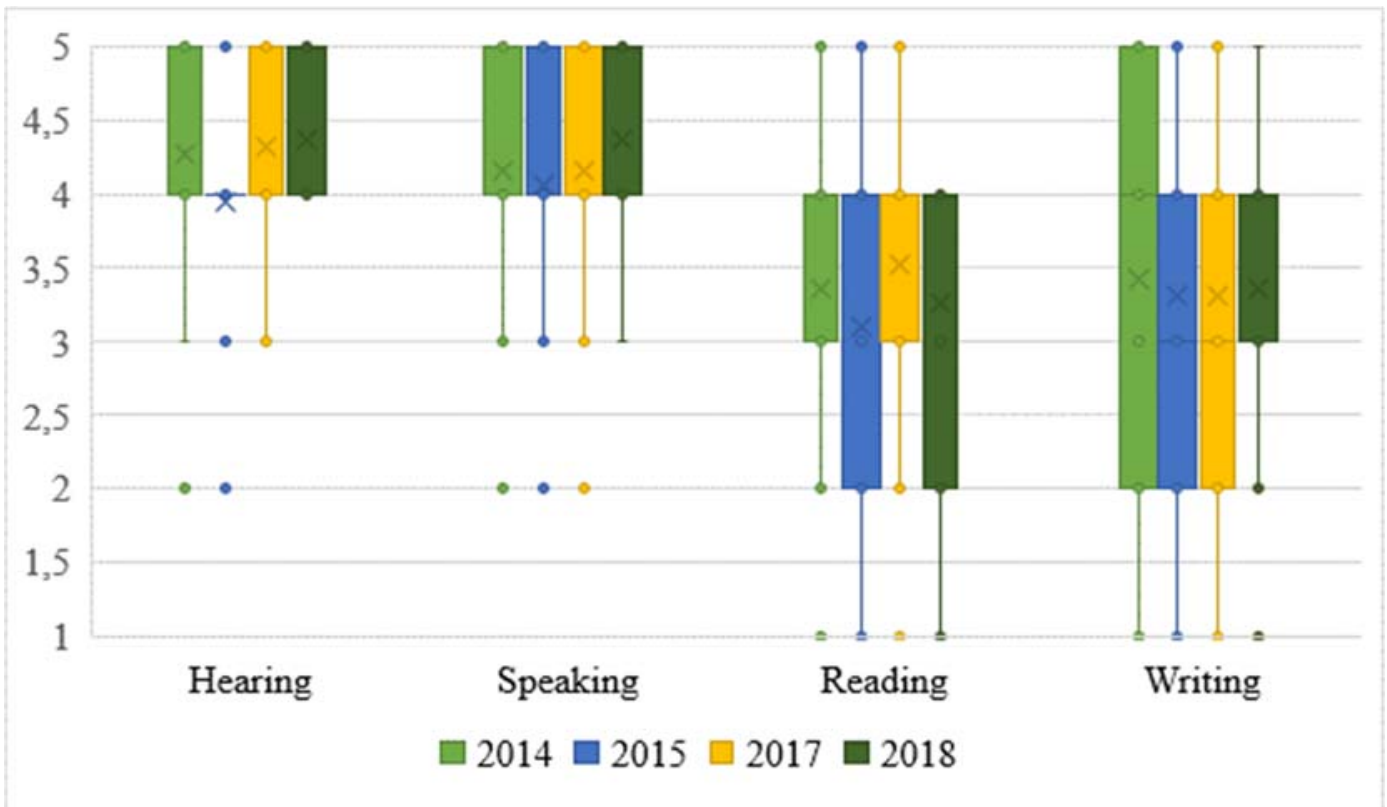

Figure 5. Assessment of statement "I like to hear / speak / read / write Russian"

To address the question of loyalty towards the heritage language, we included statements regarding the readiness of the participants to accept a partner that does (not) speak the heritage language (Question: "I would not mind having a (a) German-speaking / (b) Russian-speaking partner") and the willingness to pass the heritage language on to their own children (Question: "If I have children, I want them to first learn (a) German / (b) Russian"). Figure 6 shows the reactions to these two statements.

Our participants essentially do not care about the mother tongue of their future partners, which means that they do not exclude the possibility that their potential family language will be primarily (or only) German. This would place the whole burden of passing Russian on to their children solely on them if they decide that their children should learn Russian. Most of our participants want their children to speak Russian, but top priority is given to German if they had to choose which language their children should acquire first of all. With increasing age, the mean

${ }^{10}$ Average scores for the data obtained in the last wave of data collection (2018): Hearing: 4.37 (Russian) / 4.16 (German); Speaking: 4.37 (Russian) / 4.21 (German); Reading: 3.26 (Russian) / 3.84 (German); Writing: 3.37 (Russian) / 4.0 (German). There are no major changes in these values throughout the examined time span for German. Interestingly, however, the average scores for hearing and speaking German show a slight decrease over time, while the opposite is true for these modalities in Russian. 
rate of agreement with the statement that their children should learn Russian first is decreasing, but the fact that the majority still prefers a "neither agree nor disagree" reaction indicates that the ideal option for most of our informants is a bilingual education of their children, as can be deduced from the in-depth interviews that we conducted after the participants filled in the questionnaire.

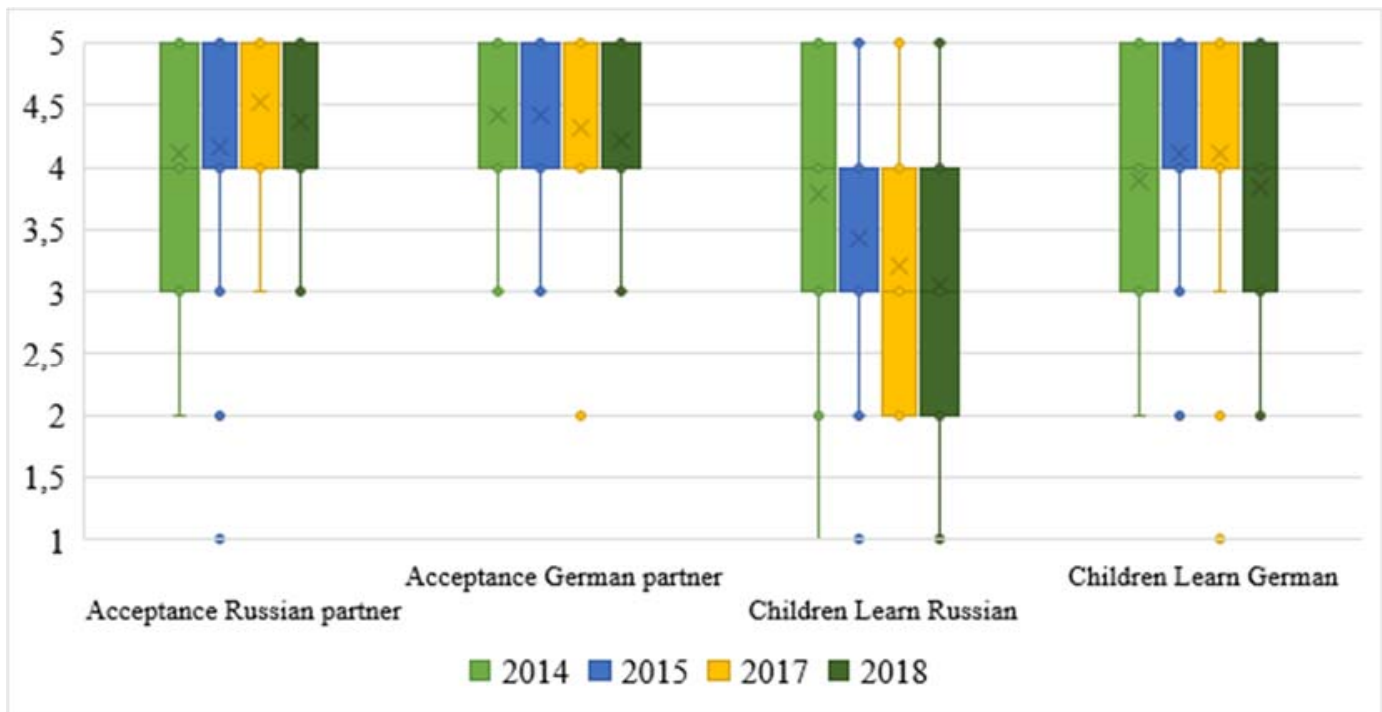

Figure 6. Assessment of statements (i) "I would not mind having a German-speaking / Russian-speaking partner" and (ii) "I want my children to first learn German / Russian"

Overall, the quantitative data from the questionnaires underline that Russian has a high emotional value for our participants. When asked why they decide to code-switch from Russian to German if a German-speaking person joins the group of otherwise bilingual interlocutors, none of our participants declared that this is due to the fact that they feel uncomfortable while speaking Russian in public. Single participants, however, admitted that they try to avoid the use of Russian in public places in Germany. ${ }^{11}$ The majority explained their code-switching behavior in these instances as a result of the wish to get themselves understood by all interlocutors and/or considered it an issue of politeness not to choose a language that is unfamiliar to single interlocutors.

\subsection{Longitudinal development of Russian language skills}

Although this paper focuses on the longitudinal development of factors which determine the sociolinguistic situation of Russian adolescent heritage speakers in Germany, we are also referring to data taken from the linguistic part of the longitudinal study where we investigated the development of proficiency in the

${ }^{11}$ A maximum of four participants chose that option in the 2015 data collection wave, two persons opted for this answer in 2014 and 2017 while only one participant in 2018 admitted that this is a relevant factor for his/her code-switching behavior. 
heritage language. Our aim is not to establish statistical relationships between the development of sociolinguistic factors and linguistic proficiency (for such an analysis compare, among others, Anstatt 2017), but to cross-check whether changes in the sociolinguistic situation are accompanied by observable trends in the development of language skills. For this purpose, we collected data on Russian language proficiency from experimental tests targeting different linguistic domains (see Section 4.2.).

\subsubsection{Development of vocabulary knowledge}

Figure 7 shows the results of the test targeting lexical proficiency in the heritage language from the longitudinal study. We replicated the same task at every data measurement point (see Section 4.2).

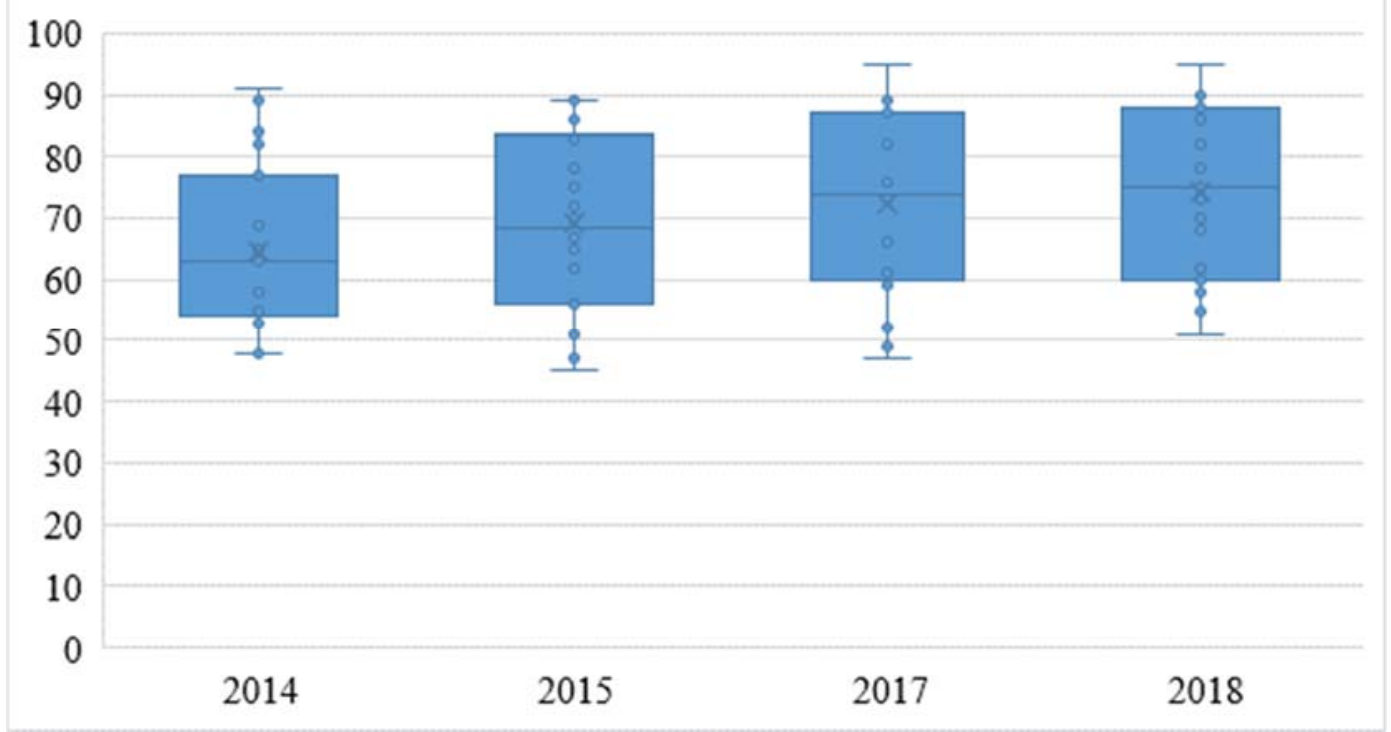

Figure 7. Development of lexical correctness scores (in \%) over time

A look at the data reveals a steady increase in average lexical correctness scores. The average correctness scores rise from $64.74 \%$ in 2014 to $74.16 \%$ in 2018 . A one-way repeated measures ANOVA yielded a highly significant improvement for the investigated time $\operatorname{span}(\mathrm{F}=21.086, \mathrm{df}=3, \mathrm{p}<.00001)$.

\subsubsection{Development of grammatical proficiency (inflectional morphology)}

Figure 8 gives an overview on the development of the morphological correctness scores (in \%) over the examined time span which we obtained from a Cloze test that targeted mostly noun and verb inflection in Russian (see Section 4.2.). 


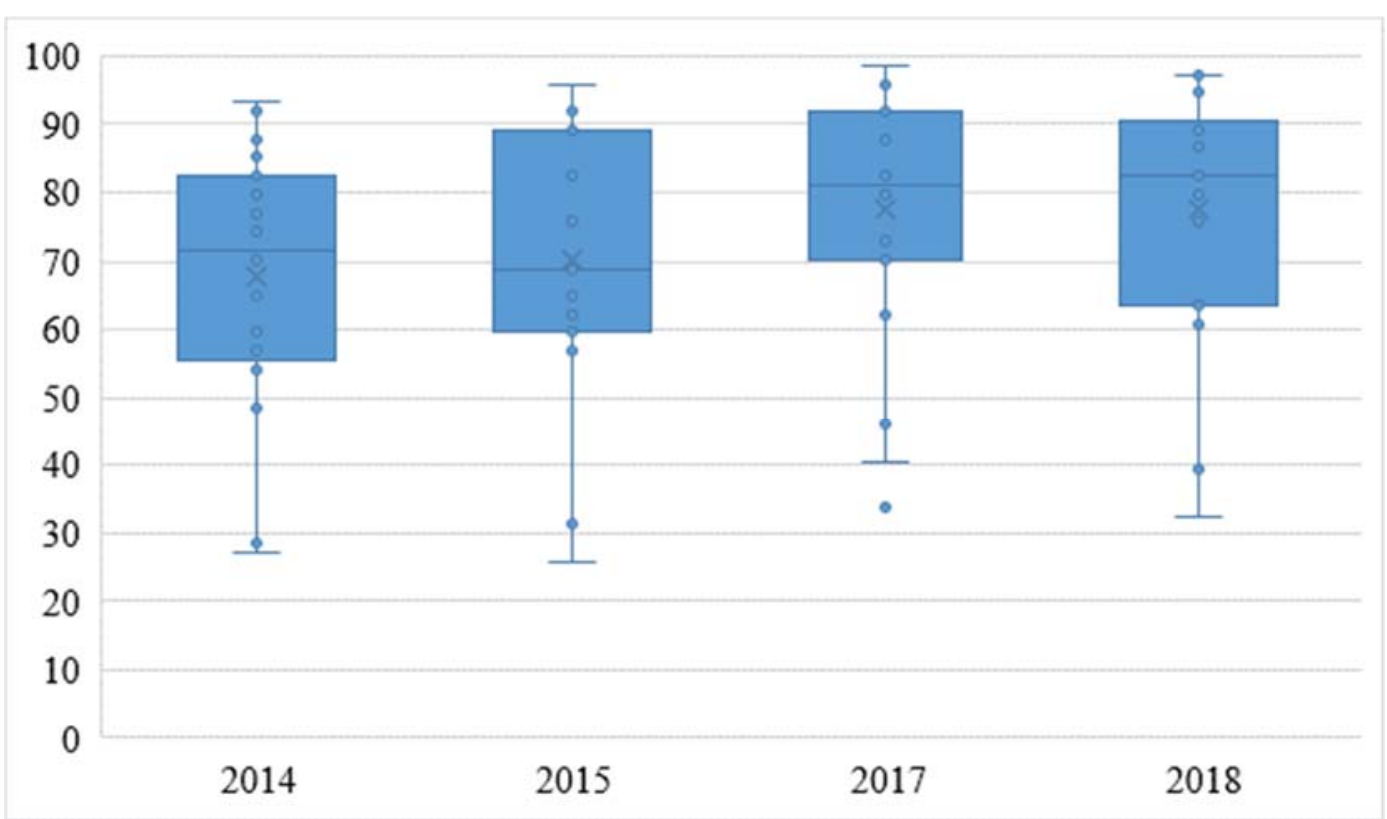

Figure 8. Development of morphological correctness scores (in \%) over time

The data, again, show an increase in morphological correctness scores over time. This increase is especially conspicuous for the period between the data measurement points two and three, when the average correctness score rose from $70.1 \%$ in 2015 to $77.5 \%$ in 2017 . A one-way repeated measures ANOVA revealed a significant difference for the investigated time $\operatorname{span}(\mathrm{F}=14.141, \mathrm{df}=3, \mathrm{p}<.00001)$.

\section{Discussion}

\subsection{Changes in sociolinguistic parameters during the examined time span (RQ1)}

The sociolinguistic parameters that according to the previous literature influence the probability of heritage language maintenance do develop in different ways. With regard to the exposure to explicit heritage language instruction two participants selected their heritage language as their second foreign language subject in school at the beginning of our study. This 'upgrading' of the status of heritage language instruction from a previous additional activity that happened in the spare time of our participants to a regular school subject certainly enhances the prospect for future heritage language maintenance for these individuals. At the same time, three participants in our sample abandoned their attendance of heritage language instruction during our longitudinal study, another three stopped attending voluntary heritage language instruction already around the time when they entered secondary school, i.e. shortly before we began collecting our data. The fact that six informants resigned from explicit heritage instruction due to motivational problems and time constraints after or shortly before entering secondary school seems to be quite typical for adolescent heritage speakers. This tendency was also attested in 
the interviews that we conducted with heritage language instructors during the project. However, given the rather long period that most of our informants were exposed to heritage language instruction in different institutions, we can presuppose that heritage language skills might have already stabilized by the time the participants stopped attending these language classes. The high level of lexical and grammatical proficiency in Russian (as well as for other modalities of heritage language proficiency that we could not report on here) that we found for most of our informants seem to corroborate this assumption.

Language exposure at home has been identified as one of the most significant factors in heritage language maintenance and transmission. Regarding this parameter, a positive development emerges from our data, as the amount of exposure the informants receive in their families remained quite stable during the longitudinal study. Despite the rather low amount of consistent use of Russian in parent-parent communication, the number of participants who claimed to use at least predominantly Russian when talking to their parents considerably increased, especially with regard to mother-child interactions. Mothers are the most active part in providing Russian input for their children (see Figure 1), which, however, might also reflect the fact that participation in our study was on a voluntary basis and therefore attracted mostly mothers and adolescents who had a certain interest in preserving the heritage language. Communication with siblings takes place mostly in the majority language German with code-switching between Russian and German being a rather common feature of these interactions. Although codeswitching regularly also occurs with other family members, an increase in regular resorting to code-switching could only be found for interactions between siblings (see Figure 2). Anstatt (2017) reported on the importance of the use of Russian as a means of communication between peers for heritage language maintenance in adolescents. This factor, however, could not have been a contributing factor to the high and stable proficiency in Russian that we found in our sample, as the composition of our participants' social networks is clearly dominated by German as the means of communication with people outside the core family, including peers. This is true for the whole time span that we covered in our study.

A negative trend could be established for the use of Russian in different domains. The number of participants who regularly visit the home countries of their parents drops towards the end of our longitudinal study. Contacts with friends and relatives in these countries are maintained largely by telephone calls and less so by social media which might be due to older relatives still residing in the countries of origin. This decrease in active contacts to Russian-speaking people in the homeland is not compensated for by a higher use of media in Russian. On the contrary, the consumption of media that require higher literacy skills remains a source of input in Russian for less than one third (writing e-mails) or half (reading books) of our participants or shows a rapid decline in use (visiting websites) during the course of our study (see Figure 4). Even passive consumption of Russian via listening to Russian music loses importance towards the end of the study. Only visual media 
like watching Russian programs or films and social media provide a constant source of regular linguistic exposure to Russian for two thirds of our participants. The preference for activities that do not require a high degree of literacy in Russian (speaking on the phone, watching TV and movies, composing short messages in social media) resembles the patterns found for media use in American heritage speakers of Russian (Carreira \& Kagan 2011), despite the very high share of participants that have at least basic literacy skills in Russian in our sample.

The attitudinal factors that we obtained from the questionnaires indicate an overall stable positive attitude towards the heritage language. Our participants feel comfortable when using Russian (especially regarding hearing and speaking Russian, less so when they have to read it or write in it) and most of them have no reservations to use it in public (see Figure 5). However, their loyalty to Russian does not go so far that the language factor is considered a key variable for selecting a future partner. This hints at a reduced need to stay (linguistically) separate from the surrounding majority community. On the other hand, they do not exclude the possibility of having a partner from the Russian-speaking community. When asked whether they want to pass Russian on to their children, nearly all participants declared the wish to do so in the interviews that followed the questionnaire, although on average they granted a higher priority to the acquisition of the majority language German (cf. Figure 6), as this is considered the key to their children's educational and professional success. Additional support for the claim that our participants exhibit a high emotional attachment to their heritage language comes from the interviews. Almost all participants are proud of having an additional language "for free" compared to their monolingually raised peers. Knowledge of Russian is mostly considered an essential part of their linguistic identity and a cultural value in itself. This parallels the findings regarding the loyal and emotional relationship to Russian in other samples of Russian-speaking adolescents in Germany (see, among others, Anstatt 2017 or Meng \& Protassova 2017). In our sample we observed a close relationship between the attitudes towards the Russian language and culture exhibited by the parents and their children (Burkhardt et al. 2018). However, when asked why they deem it important to maintain Russian, differences between the two generations emerge which relate to differences between affective and cognitive components of language attitudes (see Section 2.3.). The parents attribute a certain economic value to the knowledge of Russian, i.e., they see good proficiency in Russian as an asset on the job market in Germany, while the children place more emphasis on maintaining Russian as a sign of loyalty towards their family and their own roots, which means their attitudes are mostly affective by nature (for a similar finding see Anstatt 2017: 206f.).

\subsection{Development of proficiency in Russian}

For both investigated linguistic domains (knowledge of vocabulary and inflectional morphology) there was a positive trend in correctness scores obtained by our participants throughout the examined period. Participants received significantly higher scores towards the end of the longitudinal study. This proves 
that there are no signs of attrition with regard to lexical and morphological proficiency in Russian on the group level. One could claim that the two investigated domains do not depend on literacy development and should therefore be less vulnerable to changes in the sociolinguistic setting like the abandonment of formal instruction in the heritage language or decreasing use of Russian media. However, the observed trend is also valid for other modalities of the language skills that we investigated in the project, including reading comprehension and orthographical correctness scores. ${ }^{12}$ In sum, our participants exhibit a stable or even progressing proficiency in their heritage language.

\subsection{Predicting long-term maintenance of Russian}

Our data pose some challenges regarding predictions of further maintenance of Russian by our participants. On the one hand, there is a clear positive trend regarding proficiency in the heritage language, at least on the group level. On the other hand, there are also some indications that the exposure to Russian input is decreasing in several domains, first and foremost with regard to media consumption or personal visits to the homeland of their parents. Russian seems to be more and more restricted to intrafamily communication at home, especially to interactions with the parents, and to educational settings (classes in Russian as a heritage or foreign language). This trend is mirrored by the attitudes of our participants towards Russian, as they explicitly consider Russian important primarily for family interactions and cultural factors, but less with regard to career goals. The motivation for maintaining Russian and passing it on to the following generation is therefore, as Laleko (2013: 99) puts it, linked to seeing "Russian as a heritage language [that] retains primarily retrospective (or past-oriented), rather than prospective (or futureoriented) value for its speakers". It is for this reason that Laleko (2013: 98) concludes that Russian as a heritage language in the U.S. is in danger of being abandoned after the second generation, unless "the language begins to be viewed as having real value in the present and future lives of the speakers, rather than only as a bridge to the past". However, the essential difference - as we see it - between the American and the German context lies in the fact that in Germany access to institutional support for receiving formal instruction in the heritage language is readily available, at least in major cities. This opens up additional possibilities for obtaining and improving Russian language skills outside the family setting and does not put the whole burden on individual members of the Russian-speaking community itself (e.g., regarding the development of literacy skills in Russian and other skills available to competent speakers).

The question remains whether future generations of speakers of Russian as a heritage language will actually make use of these opportunities and whether the German society will continue to offer and expand possibilities for receiving heritage

${ }^{12}$ Literacy development in the heritage language Russian deserves a closer examination in a separate study. 
language instruction. Currently we are witnessing a change in language policy in Germany which favors a reevaluation of linguistic superdiversity in educational settings and tries to counterbalance a monolingual habitus that has dominated official language ideology in Germany for a long time. The process, however, is hampered by the federal system of Germany, where innovations in the educational sector are often restricted to the individual federal states (Bundesländer). The reevaluation of heritage languages and linguistic diversity in general could benefit from assigning a certain "market value" to these languages, which could turn the linguistic resources available to the individual speakers into a benefit on the job market. This prospect, however, also depends on the development of the political and economic climate between Germany and the Russian-speaking countries. On the one hand, heritage speakers of Russian could benefit from the traditionally close economic and cultural cooperation between Germany and Russia. On the other hand, the political and economic development in the successor states of the former Soviet Union also play a central role for future immigration or remigration processes which could lead either to a replenishment or a decrease of the number of immigrants from Russian-speaking countries. This, in turn, has an impact on the number of heritage speakers of Russian in Germany and also on the continued intergenerational language maintenance. Technical advance and global interconnectedness both in the private and trade sector offer additional possibilities for enhancing heritage language maintenance. Owing to the considerable size of the Russianspeaking community in Germany, the prospects for its continuous existence in Germany do not look as grim as some of its members or some linguists claim. After all, the experiences of other larger immigrant communities in Germany (Turkish, Italian, Greek, Serbian/Croatian) bear witness that heritage language maintenance beyond the second generation is possible.

\section{Concluding remarks}

The results of our study obviously have to be treated with some caution. First, the small sample size limits the possibilities for generalizing the trends that we highlighted in this paper by drawing on quantitative evidence from questionnaires and experimental tests on selected aspects of Russian language proficiency. Second, the time span covered in our study is five years only, which makes dramatic changes in the sociolinguistic situation of the participants rather unlikely. Future studies should cover a larger time period, preferably also the transition of participants from school into the working environment, and systematically monitor the development of both sociolinguistic factors and language skills in the heritage language. Third, our sample is certainly biased because of the high share of participants who receive(d) formal instruction in the heritage language and who are on average highly educated as almost all of them attend higher secondary school tracks. Furthermore, participation in the study was voluntary and therefore attracted mainly parents and adolescents with a certain degree of language awareness and a positive attitude towards bilingualism and biculturalism. The fact that our findings match 
the findings reported in other studies on adolescent heritage speakers of Russian in Germany (e.g., Anstatt 2017) quite well, however, indicates that the results might nevertheless be applicable to at least a certain subgroup of second-generation speakers of Russian in Germany.

The study was built on quantitative data that were presented on the group level. While this allows to highlight some common trends in the investigated sample, a more in-depth look at individual trajectories, both concerning the sociolinguistic settings as well as the linguistic development, would enable us to run a more finegrained analysis on the relevance of certain sociolinguistic parameters regarding decisions that lead to abandoning the heritage language or retaining or even expanding its use. A longitudinal investigation of individual case studies, however, lies outside the scope of the current paper. The data obtained in the semi-structured interviews that followed the questionnaires provide, however, a fruitful basis for conducting such an analysis in the near future.

(C) Bernhard Brehmer, 2021
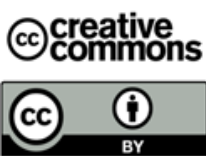

This work is licensed under a Creative Commons Attribution 4.0 International License https://creativecommons.org/licenses/by/4.0/

\section{Acknowledgments}

The research reported in this study was funded by the German Ministry of Education and Research (BMBF) from 2013 to 2019 as part of the joint research project "Russian and Polish heritage languages as a resource in school" (Grant-No. 01JM1302/1701) which was conducted at the Universities of Greifswald and Leipzig. I would like to thank all participants who took part in the longitudinal study and my collaborators in this project for helping to collect and analyze the data. Special thanks are due to the research assistants Tatjana Kurbangulova and Vladimir Arifulin who collected the Russian data in this project.

\section{REFERENCES}

Achterberg, Jörn. 2005. Zur Vitalität slavischer Idiome in Deutschland. Eine empirische Studie zum Sprachverhalten slavophoner Immigranten. München: Sagner.

Anstatt, Tanja. 2013. "Man hat sich eingelebt und angepasst". Wie russisch-deutsche Studierende ihre Sprachsituation sehen. In Gerald Bernhard \& Franz Lebsanft (eds.), Mehrsprachigkeit im Ruhrgebiet, 133-152. Tübingen: Stauffenburg.

Anstatt, Tanja. 2017. Language attitudes and linguistic skills in young heritage speakers of Russian in Germany. In Ludmila Isurin \& Claudia Maria Riehl (eds.), Integration, Identity and Language Maintenance in Young Immigrants: Russian Germans or German Russians, 197-224. Amsterdam: John Benjamins.

Armon-Lotem, Sharon, Joel Walters \& Natalia Gagarina. 2011. The impact of internal and external factors on linguistic performance in the home language and in L2 among RussianHebrew and Russian-German preschool children. Linguistic Approaches to Bilingualism 1 (3). 291-317.

Behrend, Nina. 2014. Im Spannungsfeld zwischen Herkunftssprache, Dialekt und Standardsprache: Migration und Remigration am Beispiel russlanddeutscher und 
russischsprachiger Zuwanderer aus der ehemaligen Sowjetunion. Deutsche Sprache 14 (3). 218-236.

Benmamoun, Elabbas, Silvina Montrul \& Maria Polinsky. 2013. Heritage languages and their speakers: Opportunities and challenges for linguistics. Theoretical Linguistics 39 (3-4). 129-181.

Besters-Dilger, Juliane. 2013. Russian in Germany: Intermediate results on L1 attrition. In Michael Moser \& Maria Polinsky (eds.), Slavic Languages in Migration, 189-204. Wien: LIT.

Böhmer, Jule. 2015. Biliteralität. Eine Studie zu literaten Strukturen in Sprachproben von Jugendlichen im Deutschen und Russischen. Berlin-New York-Münster: Waxmann.

Brehmer, Bernhard. 2007. Sprechen Sie Qwelja? Formen und Folgen Russisch-Deutscher Zweisprachigkeit in Deutschland. In Tanja Anstatt (ed.), Mehrsprachigkeit bei Kindern und Erwachsenen: Erwerb, Formen, Förderung, 163-185. Tübingen: Attempto.

Brehmer, Bernhard \& Tatjana Kurbangulova. 2017. Lost in Transmission? Family language input and its role for the development of Russian as a heritage language in Germany. In Ludmila Isurin \& Claudia Maria Riehl (eds.), Integration, Identity and Language Maintenance in Young Immigrants: Russian Germans or German Russians, 225-268. Amsterdam: John Benjamins.

Brehmer, Bernhard, Tatjana Kurbangulova \& Martin Winski. 2017. Measuring lexical proficiency in Slavic heritage languages: A comparison of different experimental approaches. In Tanja Anstatt, Christina Clasmeier \& Anja Gattnar (eds.), Slavic Languages in Psycholinguistics. Chances and Challenges for Empirical and Experimental Research, 225-256. Tübingen: Narr.

Brehmer, Bernhard \& Grit Mehlhorn. 2015. Russisch als Herkunftssprache in Deutschland: Ein holistischer Ansatz zur Erforschung des Potenzials von Herkunftssprachen. Zeitschrift für Fremdsprachenforschung 26 (1). 83-121.

Brehmer, Bernhard \& Grit Mehlhorn. 2018. Unterricht in den Herkunftssprachen Russisch und Polnisch: Einstellungen und Effekte. In Grit Mehlhorn \& Bernhard Brehmer (eds.), Potenziale von Herkunftssprachen: Sprachliche und Außersprachliche Einflussfaktoren, 259-292. Tübingen: Stauffenburg.

Brehmer, Bernhard \& Irina Usanova. 2017. Biscriptality and heritage language maintenance: Russian in Germany. In Hagen Peukert \& Ingrid Gogolin (eds.), Dynamics of Linguistic Diversity, 99-121. Amsterdam: John Benjamins.

Burkhardt, Johanna, Grit Mehlhorn \& Maria Yastrebova. 2018. Spracheinstellungen in polnisch- und russischsprachigen Familien in Deutschland. In Grit Mehlhorn \& Bernhard Brehmer (eds.), Potenziale von Herkunftssprachen. Sprachliche und Außersprachliche Faktoren, 165-183. Tübingen: Stauffenburg.

Carreira, Maria \& Olga Kagan. 2011. The results of the National Heritage Language Survey: Implications for teaching, curriculum design, and professional development. Foreign Language Annals 43 (3). 40-64.

Dietz, Barbara \& Heike Roll. 2017. Ethnic German and Jewish immigrants from post-Soviet countries in Germany: Identity formation and integration prospects. In Ludmila Isurin \& Claudia Maria Riehl (eds.), Integration, Identity and Language Maintenance in Young Immigrants: Russian Germans or German Russians, 41-67. Amsterdam: John Benjamins.

Dubinina, Irina \& Maria Polinsky. 2013. Russian in the USA. In Michael Moser \& Maria Polinsky (eds.), Slavic Languages in Migration, 161-187. Wien: LIT.

Dück, Katharina. 2020. Russisch. In Rahel Beyer \& Albrecht Plewnia (eds.), Handbuch der Sprachminderheiten in Deutschland, 303-349. Tübingen: Narr-Francke-Attempto. 
Eriksson, Svetlana. 2015. Societal, community, family, and individual factors affecting Russian language maintenance in migrant families in Ireland. Russian Journal of Communication 7 (2). $150-163$.

Gagarina, Natalia \& Annegret Klassert. 2018. Input dominance and development of home language in Russian-German Bilinguals. Frontiers in Communication-Language Sciences 3. 40. https://www.frontiersin.org/articles/10.3389/fcomm.2018.00040/full (accessed 10 August 2021).

Garrett, Peter. 2010. Attitudes to Language. Cambridge: Cambridge University Press.

Irwin, Vera. 2017. When networks tell just half the story: Social networks, language and social identity among Russian German and Russian Jewish migrants in Germany. In Ludmila Isurin \& Claudia Maria Riehl (eds.), Integration, Identity and Language Maintenance in Young Immigrants: Russian Germans or German Russians, 99-134. Amsterdam: John Benjamins.

Isurin, Ludmila. 2011. Russian Diaspora: Culture, Identity, and Language Change. BerlinBoston: de Gruyter.

Isurin, Ludmila \& Claudia Maria Riehl (eds.). 2017. Integration, Identity and Language Maintenance in Young Immigrants: Russian Germans or German Russians. Amsterdam: John Benjamins.

Kagan, Olga. 2005. In support of a proficiency-based definition of heritage language learners: A case of Russian. International Journal of Bilingual Education and Bilingualism 8 (2). 213-221.

Kamusella, Tomasz. 2013. Migration or immigration? Ireland's new and unexpected Polishlanguage community. In Michael Moser \& Maria Polinsky (eds.), Slavic Languages in Migration, 205-231. Wien: LIT.

Karpava, Sviatlana, Natalia Ringblom \& Anastassia Zabrodskaja. 2018. Language ecology in Cyprus, Sweden and Estonia: Bilingual Russian-speaking families in multicultural settings. Journal of the European Second Language Association 2 (1). 107-117.

Kopeliovich, Shulamit. 2010. Family language policy: A case study of a Russian-Hebrew bilingual family: Toward a theoretical framework. Diaspora, Indigenous, and Minority Education 4 (3). 162-178.

Kreß, Beatrix. 2014. "Was habt ihr Neues erfahren, wovon ihr vorher nichts wusstet?" Diskursive Formen der Wissensverarbeitung im russischen Sprachförderunterricht. Zeitschrift für Interkulturellen Fremdsprachenunterricht 19 (1). 169-182.

Levkovych, Nataliya. 2012. Po-russki in Deutschland: Russisch und Deutsch als Konkurrenten in der Kommunikation mehrsprachiger Gruppen von Personen mit postsowjetischem Hintergrund in Deutschland. Bochum: Brockmeyer.

Laleko, Oksana. 2013. Assessing heritage language vitality: Russian in the United States. Heritage Language Journal 10 (3). 382-395.

Lo Bianco, Joseph. 2008. Organizing for multilingualism: Ecological and sociological perspectives. In Keeping Language Diversity Alive: A TESOL Symposium, 1-18. Alexandria, VA: Teachers of English to Speakers of Other Languages.

Lo Bianco, Joseph \& Joy Kreeft Peyton. 2013. Vitality of heritage language in the United States: The role of capacity, opportunity and desire. Heritage Language Journal 10 (3). 1-8.

Lokshin, Pavel. 2020. Wie viele Russischsprachige leben in Deutschland? Mediendienst Integration. https://mediendienst-integration.de/artikel/wie-viele-russischsprachige-lebenin-deutschland.html (accessed 10 August 2021).

Meng, Katharina. 2001. Russlanddeutsche Sprachbiografien: Untersuchungen zur sprachlichen Integration von Aussiedlerfamilien. Tübingen: Narr.

Meng, Katharina \& Ekaterina Protassova. 2003. Deutsche, Russlandsdeutsche, RusseDeutsche, rusaki - Selbstbezeichnungen und Selbstverständnisse nach der Aussiedlung. 
In Jürgen Erfurt (ed.), "Multisprech": Hybridität, Variation, Identität, 173-202. Osnabrück: OBST.

Meng, Katharina \& Ekaterina Protassova. 2009. Cultural self-conceptions and group designations of Russian-German immigrants in Germany. In Bert Cornillie, José Lambert \& Pierre Swiggers (eds.), Linguistic Identities, Language Shift and Language Policy in Europe, 135-149. Leuven: Peeters.

Meng, Katharina \& Ekaterina Protassova. 2013. Deutsche or rusaki? Transformations of the cultural self-conceptions after (r)emigration. In Inke Du Bois \& Nicole Baumgarten (eds.), Multilingual Identities: New Global Perspectives, 67-84. Frankfurt/M.: Peter Lang.

Meng, Katharina \& Ekaterina Protassova. 2017. Young Russian-German adults 20 years after their repatriation to Germany. In Ludmila Isurin \& Claudia Maria Riehl (eds.), Integration, Identity and Language Maintenance in Young Immigrants: Russian Germans or German Russians, 159-196. Amsterdam: John Benjamins.

Otwinowska, Agnieszka, Natalia Meir, Natalia Ringblom, Sviatlana Karpava \& Francesca La Morgia. 2021. Language and literacy transmission in heritage language: Evidence from Russian-speaking families in Cyprus, Ireland, Israel and Sweden. Journal of Multilingual and Multicultural Development 42 (4). 357-382.

Remennick, Larissa. 2003. From Russian to Hebrew via HebRush: Intergenerational patterns of language use among former Soviet immigrants in Israel. Journal of Multilingual and Multicultural Development 24 (5). 431-453.

Ries, Veronika. 2013. "Da Kommt Das so Quer Rein" - Sprachgebrauch und Spracheinstellungen Russlanddeutscher in Deutschland. Berlin-New York-Münster: Waxmann.

Rodina, Yulia, Tanja Kupisch, Natalia Meir, Natalia Mitrofanova, Olga Urek \& Marit Westergaard. 2020. Internal and external factors in heritage language acquisition: Evidence from heritage Russian in Israel, Germany, Norway, Latvia and the United Kingdom. Frontiers in Education https://www.frontiersin.org/articles/10.3389/ feduc.2020.00020/full (accessed 10 August 2021).

Schmid, Monika S. \& Elise Dusseldorp. 2010. Quantitative analyses in a multivariate study of language attrition: The impact of extralinguistic factors. Second Language Research 26 (1). 125-160.

Schnar, Natalie. 2010. Sprache als Kriterium ethnischer Identität: Eine empirische Studie zum Stellenwert des Russischen im Ethnizitätskonzept Russlanddeutscher Jugendlicher in der Diaspora Deutschland. Hamburg: Dr. Kovač.

Statistisches Bundesamt. 2018. Bevölkerung mit Migrationshintergrund. Ergebnisse des Mikrozensus 2017. Wiesbaden: Destatis.

Warditz, Vladislava. 2019. "Fathers" and "children": Functions of word formation in spoken Russian of two generations of bilingual immigrants. In Ol'ga I. Glazunova (ed.), Russkaya Grammatika: Strukturnaya Organizatsiya Yazyka $i$ Processy Yazykovogo Funkcionirovaniya, 418-426. Sankt-Peterburg: URSS. (In Russ.)

Zemskaja, Elena A. (ed.). 2001. Russian Language Abroad: General Processes and Speech Portraits. Moskva-Vena: Yazyki staroslavyanskoi kul'tury. (In Russ.)

Ždanova, Vladislava. 2004. Kommunikatives Verhalten russischsprachiger Emigranten als Indikator ihrer soziokulturellen Orientierungen. In Markus Bayer, Michael Betsch \& Joanna Błaszczak (eds.), Beiträge der Europäischen Slavistischen Linguistik (POLYSLAV) 7, 244-251. München: Otto Sagner.

Ždanova, Vladislava. 2008a. Stylistic processes in the language of the Russian diaspora. In Elena Graf, Nadine Thielemann \& Rafał Zimny (eds.), Beiträge der Europäischen Slavistischen Linguistik (POLYSLAV) 11, 279-287. München: Otto Sagner. (In Russ.) 
Ždanova, Vladislava. 2008b. "Russkii i rossiiskii" in the language of the homeland and diaspora as a projection of individual identity. Etnolingwistyka 20. 187-202. (In Russ.)

\section{Article history:}

Received: 22 May 2021

Accepted: 20 October 2021

\section{Bionote:}

Bernhard BREHMER, PhD, Full Professor of Slavic Linguistics at the Department of Linguistics at the University of Konstanz (Germany). Research Interests: Heritage Language acquisition and maintenance, language contact and cross-linguistic influence, L1 attrition, Heritage Russian and Polish, Phonetics, Morphology, Morphosyntax, Syntax, Pragmatics (politeness and forms of address), Literacy development (esp. writing).

\section{Contact information:}

Department of Linguistics

University of Konstanz

Universitätsstr. 10

78464 Konstanz, Germany

e-mail: bernhard.brehmer@uni-konstanz.de

ORCID: 0000-0002-5065-7719

\section{Сведения об авторе:}

Бернхард БРЕМЕР - доктор филологических наук, профессор славянского языкознания на кафедре общей лингвистики Констанцского университета (Германия). Сфера научных интересов: освоение и сохранение эритажных языков, языковой контакт и межъязыковые взаимодействия, утрата первого (родного) языка, русский и польский языки как эритажные, фонетика, морфология, морфосинтаксис, синтаксис, прагматика (формы вежливости и обращения), формирование грамотности.

\section{Контактная информация:}

Department of Linguistics

University of Konstanz

Universitätsstr. 10

78464 Konstanz, Germany

e-mail: bernhard.brehmer@uni-konstanz.de

ORCID: 0000-0002-5065-7719 